\title{
Architectural Design as a Tool of Social Integration
}

\section{Architektonický návrh jako nástroj sociální integrace}

\author{
Karolína Kripnerová \\ Fakulta architektury, České vysoké učení technické v Praze, Česká republika \\ karolina.kripnerova@fa.cvut.cz
}

\begin{abstract}
This research aims to explore the role of architecture in the field of social integration, particularly in the prevention of homelessness. It describes the state of the problem and the target group - the research is aimed at young people coming out of institutional care. It presents the already identified recommendations and conclusions concerning the principles of design, and foreign inspiration for the Czech environment.
\end{abstract}

KEYWORDS: homelessness; architecture; design; integration; prevention

\begin{abstract}
ABSTRAKT: Uvedený výzkum si klade za cíl prozkoumat úlohu architektury na poli sociální integrace, v prevenci bezdomovectví. Představuje stav problematiky a cílovou skupinu, na kterou je výzkum zaměřen - na mladé lidi vycházející z ústavní péče. Předkládá doporučení a závěry, kterých bylo dosud dosaženo ohledně principů navrhování. Uvádí zahraniční inspiraci pro české prostředí.
\end{abstract}

KLÍČOVÁ SLOVA: bezdomovectví; architektura; navrhování; integrace; prevence

\section{Úvod}

Prezentovaný výzkum se soustředí na problematiku sociální integrace, konkrétně na prevenci bezdomovectví, z pohledu architektury. 
Bezdomovectví je symbolem extrémního sociálního vyloučení. Sociální vyloučení úzce souvisí s městem a dostupností bydlení - kdo bydlí, má domov a sociální vazby, někam patří. Kdo ale nebydlí, ztrácí prátele, vazby, kontakty. Zůstává na ulici. Sám. Sociální vyloučení souvisí také s kvalitou veřejného prostoru, s chováním obyvatel města, jejich péčí, všímavostí, jejich předsudky či empatií.

Bezdomovcem se může stát každý, je to bohužel jednodušší, než si myslíme. Rozvod, ztráta zaměstnání, psychické problémy. Jednu z nejohroženějších skupin tvoří mladí lidé vycházející z ústavní péče. Dle statistik Projektu Šance prošlo až 70 \% jeho klientů dětskými domovy. (1)

Pohled z druhého konce - pro město znamená následné řešení komplikované situace lidí bez domova (noclehárny, terénní pracovníci a další sociální služby) vysokou položku v rozpočtu. (2) Shrnuto - je důležité se tímto tématem zabývat a hledat různé cesty, jak předcházet tomu, aby se lidé na ulici ocitli.

Architekt má kompetence měnit a kultivovat své okolí, formulovat vize. Cílem výzkumu je najít pro architekturu a jejího tvůrce vhodné úkoly, kterými by mohl přispět $\mathrm{k}$ prevenci bezdomovectví. Zároveň se výzkum snaží ve vztahu $\mathrm{k}$ daným úkolům hledat odpovědi na otázky a možná řešení.

\section{Bezdomovectví a sociální služby ve městě}

Pro problematiku bezdomovectví se užívá více dělení a definic. Pro svou práci vycházím z definice Evropské federace národních sdružení pracujících $s$ bezdomovci (FEANTSA) zvané ETHOS (z anglického European Typology on Homelessness and Housing Exclusion), která chápe bezdomovectví jako souhrnné označení pro heterogenní populační skupinu. Tuto heterogenní skupinu dále dělí na čtyři podskupiny.

Zaprvé se jedná o viditelné bezdomovce, tedy osoby, které vídáme spát na lavičkách a v parcích. Jsou to lidé zcela bez střechy nad hlavou. Druhou podskupinu tvoří lidé, kteří bydlí na ubytovnách a v noclehárnách. Nemohou si z různých důvodů zajistit jiné, stabilní bydlení. Třetí podskupinu tvoří lidé, kteří „bydlí“ pod mostem, v chatkách či na jiných místech, která nevyhovují společenským standardům bydlení. Poslední podskupina je bezdomovectvím „pouze“ ohrožena - nemá jisté bydlení a přespává u př́ibuzných či známých. (3) Do této skupiny se bohužel často dostanou lidé vycházející z ústavní péče. Nemají rodinné zázemí a podporu, nemají se s kým poradit a kam se vrátit.

Jak je z uvedeného vidět, definice boří a rozšiřuje jednu ze zažitých stereotypních představ společnosti o tom, kdo je bezdomovec. 
Lidem v těžkých životních situacích se stát, město a různé neziskové organizace snaží pomoci prostřednictvím palety sociálních služeb. Od terénních programů přes azylové domy a domy na půli cesty až po sociální bydlení. Pro pobytové sociální služby jsou často vyhrazovány veřejné pozemky a budovy, které se bud' nehodí ke komerčnímu využití, nebo je neumí jinak využít ani samo město. Nacházejí se na okraji města či v jeho méně atraktivních částech. (4) „Nevědomky“ tak společnost znevýhodněné lidi směruje zpět do problémových míst.

Ve své práci se zaměřuji na domy na půli cesty. Domy na půli cesty patří do služeb sociální prevence, nabízí ubytování mladým lidem, kteří vyrůstali v ústavní péči (dětské domovy), popř́ípadě přicházejí z nápravných nařízení, anebo se z různých důvodů rozhodli opustit rodinu. Domy na půli cesty svým obyvatelům pomáhají překonat těžký krok osamostatnění se a vstupu do dospělého života. Obyvatelé jsou většinou vnitřně zranění a hluboce traumatizovaní mladí lidé, kteří potřebují podpořit ve vzdělávání a v práci, získat místo, kde se mohou poradit a kam se mohou vracet, a ze všeho nejvíce potřebují navázat sociální vazby, a získat tak své místo ve společnosti.

\section{Dostupnost pramenů}

O navrhování objektů pro ubytovací služby pro lidi bez domova či obecně o tématu bezdomovectví z pohledu architekta není zatím v České republice dostupné mnoho literatury. Tématu se věda začíná věnovat až po roce 1989, do té doby bylo bezdomovectví de facto tabu. (5) Již ale probíhají četné výzkumy situace v České republice. Zmíním alespoň projekt HOBOhemia, výzkum Sociologického ústavu Akademie věd ČR, který se na problematiku bezdomovectví soustředí.

Architektonický pohled na věc můžeme najít v zahraniční literatuře - k nejprobádanějším patři například americká scéna. Americká literatura a americké studie uvádějí dobré př́íklady staveb pro sociální služby z tamního prostř̌edí, jejich analýzy a závěry. (6) V českém prostředí je však americký přístup možno brát pouze jako inspiraci, jak zpracovávat analýzu. Americké stavby nejsou svým měřítkem pro české prostředí vhodné: kapacity zařízení se pohybují i kolem několika set lůžek na jednom místě. Je př́ihodné zmínit, že v zařízeních sociální pomoci v celém hlavním městě Praze je kolem 800 lůžek. (7)

\section{Inspirace z Vídně}

Pionýrský vídeňský projekt Vinzi-Rast Mittendrin+Lokal (studio Gaupenraub+/-) boří tradiční pohled na sociální problémy měst. Charitativní společnost Sv. Vincenta de Paul na podnět studentů adaptovala historický biedermeierovský objekt v širším 
centru rakouské metropole na místo společného bydlení studentů a lidí původně bez domova. Svou sociální vizi, kdy každému dává rovnocennou šanci (ubytování i nabídku práce), hrdě ukazuje celému městu a veřejnosti.

\section{Pracovní hypotéza}

Kvalitní architektura staveb pro sociální služby může výrazně přispět k prevenci bezdomovectví.

\section{Research by design}

Metoda research by design je typická pro architekturu. V rámci tohoto výzkumu pracuji na návrhu nového konceptu domu na půli cesty. Koncept se zakládá na konzultování problematiky s odborníky na dané téma - sociálními pracovníky a dalšími lidmi, kteří v domech na půli cesty, azylových domech či v jiných službách pro lidi bez domova pracují. Dále vychází z konzultací se zahraničními architekty, autory představeného vídeňského projektu. V neposlední řadě uplatňuji vlastní rešerše a poznatky z kontaktu s lidmi bez domova během dobrovolnické práce.

Samozrejmostí dnešního navrhování by měl být koncept udržitelné architektury. Ta představuje komplexní př́stup, který je ekologický a ekonomický, ale též udržitelný po stránce sociální a kulturní.

Všechny tři body jsou také důležité právě při navrhování pro lidi bez domova. Zmíním zvláště přístup ekonomický, který reflektuje neziskovost projektů pro zmíněné sociální služby. Rozhodně to však neznamená, že by se tyto projekty měly vždy řešit tou nejlevnější cestou. Je nutné dobře a účelně alokovat prostředky, vědět, kde je možné ušetřit a kde naopak přidat.

Třetí pilír udržitelné architektury - sociální - je pro svou exaktní neuchopitelnost $\mathrm{v}$ četných projektech opomíjen. $\mathrm{V}$ problematice stavění pro lidi bez domova je však téměř tím nejdůležitějším, na čem udržitelnost stavby stojí. V navrhování budov pro lidi bez domova tím pádem - více než kdy jindy - zaujímají dủležité místo pojmy jako identita stavby, zabydlenost, měŕítko a vztah k místu a městu.

Identita a zabydlenost reflektují složitou minulost obyvatel navrhovaného domu, kteří se cítí dobře $\mathrm{v}$ místech, kde je znát jeho historie, např́ílad díky původnímu vybavení, či kde jsou zřetelné charaktery materiálů (struktura, proměnlivost). Měřítko stavby je důležité ve vztahu k obyvatelům: odvíjí se od vhodného počtu lidí, který je schopen tvořit komunitu, tedy prostředí pro tvorbu sociálních vazeb. Dále měřítko stavby zásadně ovlivňuje její přijetí sousedy a veřejností. Pokud není úměrné oblasti, 
stává se stavba pro své sousedy zátěží. Další důležitou volbou při navrhování je poloha projektu ve městě. Objekty pro zmíněné sociální služby je třeba chápat jako potenciálně problémové, a tomuto předobrazu společnosti je proto třeba maximálně předcházet umístěním na viditelné, přehledné a dostupné místo v širším centru města.

Projekt zpracovávaný $\mathrm{v}$ rámci tohoto výzkumu nabízí ubytování studentům spolu s mladými lidmi, kteří vycházejí z ústavní péče. Návrh ctí několik zásad, které jsou zároveň průběžnými závěry výzkumu. Stanoví důležitost účinku objektu na veřejnost - dům nabízí služby (ubytování, vzdělávací kurzy a zaměstnání) obyvatelům, je ale i př́nosem pro své okolí: v přízemí je sociální podnik - kavárna, dále zde veřejnost může navštěvovat vzdělávací kurzy a přednášky nebo využívat služby dílen - např́íklad opravny kol. Veřejnost může vejít a poznat, co se uvnitř děje, kdo v budově bydlí. Druhým bodem je koncepce vlastního bydlení, která klade důraz na stupňování soukromí. Reflektuje tak složitou minulost obyvatel, každý si může vybrat, co mu vyhovuje: od zcela soukromých pokojů přes zázemí bytu (koupelna a kuchyňka), které sdílí dva spolubydlící. Pro celé patro (osazenstvo čítající osm lidí) funguje společná kuchyně. Nejvyšším stupněm otevřenosti je zázemí domu, které využívají všichni obyvatelé domu a kde dochází také $\mathrm{k}$ interakci s veřejností. Typickým př́íkladem je sociální podnik, ve kterém obyvatelé najdou práci a který jako službu využívá veřejnost. Třetím důležitým bodem jsou vertikální a horizontální komunikace $\mathrm{v}$ domě, kdy z každého společného prostoru vedou cesty dvěma směry. Tento princip vychází z potenciální rozdílnosti obyvatel a umožňuje každému volbu - koho chce potkat a koho ne.

\section{Závěr}

Uvedený výzkum se zaměřuje na úlohu architektury v prevenci bezdomovectví. Definuje základní východiska při navrhování staveb pro sociální služby - domů na půli cesty. Jsou to následující body: promísení skupin obyvatel (např́íklad lidí vycházejících z ústavní péče se studenty), př́nos domu pro jeho okolí, dále princip odstupňovaného soukromí a vzájemné propojení společných prostor v domě.

\section{Prameny a poznámky}

1 MUSÁlKOVÁ, Zuzana. Jak se žije mladým bezdomovcům. Novinky [online]. 17. února 2013. [vid. 12. března 2016]. Dostupné z: http://www.novinky.cz/zena/sty1/293286-jak-se-zije-mladym-bezdomovcum.html

2 ČTK. Praha tuto zimu vydala na opatření pro bezdomovce osm milionů korun Deník [online]. 13. května 2016. [vid. 13. května 2016]. Dostupné z:http://www. 
denik.cz/praha/praha-tuto-zimu-vydala-na-opatreni-pro-bezdomovce-osm-milionu-korun-20160512.html

3 Koncepce prevence a řešení problematiky bezdomovectví v České republice do roku 2020. Praha: MPSV, 2013. ISBN 978-80-7421-072-3.

4 FIALOVÁ, Lucie. V Prosecké ulici vznikne azylový dům. Právo - Praha - střední Čechy [online]. 30. srpna 2014. [vid. 5. září 2015]. Dostupné z: http://www.marketaadamova.cz/v-prosecke-ulici-vznikne-azylovy-dum-192.html

5 VAŠÁT, Petr. Studium bezdomovectví v USA: inspirace pro výzkum v České republice. In: ČESKÝ LID 99. 2012, 2012(2), 130.

6 DAVIS, Sam. Designing for the homeless: architecture that works. Berkeley: University of California Press, c2004. ISBN 05-202-3525-8

7 MPSV. Databáze Informačního portálu a databáze služeb sociální prevence pro osoby ohrožené sociálním vyloučením. [online] [vid. 7. září 2016] Dostupné z: https://sluzbyprevence.mpsv.cz/ 